\title{
Komunikasi Pendidik PAUD terhadap Perkembangan Bahasa Anak Usia Dini Se kecamatan Rumbai
}

\author{
Heleni Filtri ${ }^{1)}$, Sean Marta Efastri ${ }^{2)}$ \\ Universitas Lancang Kuning \\ ${ }^{1)}$ Email: heleni@unilak.ac.id \\ ${ }^{2)}$ Email: seanmarta@unilak.ac.id
}

\begin{abstract}
Abstrak: Pendidikan Anak Usia Dini Merupakan salah satu lembaga pendidikan awal bagi anak untuk mengembangkan seluruh potensi anak termasuk didalamnya perkembangan Bahasa anak Berdasarkan Undang- Undang No.20 tahun 2003 menerangkan bahwa Taman Kanak-Kanak merupakan wadah pendidikan khususnya bagi anak usia dini, untuk dapat mengembangkan seluruh aspek yang ada di dalam diri anak seperti psikomotor, kognitif, dan afektif, yang mana keseluruhannya terdapat dalam pembiasaan dan kemampuan dasar anak didik. Bahasa berfungsi sebagai salah satu alat komunikasi dan merupakan sarana penting dalam kehidupan anak. Melalui bahasa, anak dapat saling berhubungan, saling berbagi pengalaman, dan dapat meningkatkan intelektual, yakni dalam rangka pengembangan pengetahuan dan keterampilan bahasanya. Masa AUD menempati posisi yang paling penting dalam perkembangan otaknya. Selanjutnya dinyatakan bahwa karena perkembangan otaknya tersebut usia 0-8 tahun disebut sebagai usia emas (golden age). Oleh karena itu, pendidikan AUD dirasa penting karena menentukan keberhasilan anak selanjutnya. Untuk melihat keberhasilan tersebut, antara lain dapat dilihat dari perkembangan penguasaan bahasanya yang dapat dilihat ketika anak berkomunikasi. Metode Penelitian yang digunakan adalah deskriptif kuantitatif. Tujuan dari penelitian ini agar perkembangan bahasa anak berkembang secara optimal khususnya dalam komunikasi yang dilakukan oleh pendidik PAUD. Berdasarkan Hasil analisis data menunjukkan bahwa pola komunikasi guru dan cara guru dalam berkomunikasi dengan anak cukup baik. Sedangkan respon anak belum muncul. Adapun hambatan yang dialami guru dalam berkomunikasi karena anak kurang aktif dalam pembelajaran. Upaya guru dalam menghadapi hambatan tersebut adalah menstimulus anak agar responnya aktif dengan strategi guru melakukan diskusi dan simulasi serta membuat media yang kreatif.
\end{abstract}

Kata Kunci : Pola Komunikasi, Perkembangan Bahasa AUD 


\title{
Communication of PAUD Educators on Language Development for Early Childhood sub-district of Rumbai
}

\begin{abstract}
Early Childhood Education is one of the early educational institutions for children to develop all the potential of children, including the development of children's language. Based on Law No.20 of 2003 explains that Kindergarten is a place of education especially for early childhood, in order to develop all aspects that exist in the child such as psychomotor, cognitive, and affective, which are all in the basic habituation and ability of students. Language functions as one of the communication tools and is an important tool in a child's life. Through language, children can relate to each other, share experiences, and can improve intellectually, namely in the context of developing knowledge and language skills. The AUD period occupies the most important position in the development of his brain. Furthermore it was stated that because of the development of the brain aged 0-8 years it was called the golden age. Therefore, AUD education is considered important because it determines the success of the next child. To see the success, among others, can be seen from the development of mastery of the language that can be seen when children communicate. The research method used is descriptive quantitative. The purpose of this study is that the development of children's language develops optimally especially in the communication carried out by PAUD educators. Based on the results of data analysis shows that the pattern of teacher communication and the way the teacher communicates with the child is quite good. Whereas the child's response has not yet emerged. The obstacles experienced by teachers in communicating because children are less active in learning. The efforts of teachers to deal with these obstacles are to stimulate children so that their responses are active with the teacher's strategy of discussing and simulating and creating creative media.
\end{abstract}

Keywords: Communication Patterns, AUD Language Development

\section{PENDAHULUAN}

Pendidikan Anak Usia Dini sebagai salah satu lembaga pendidikan awal bagi anak untuk mengembangkan seluruh potensi anak termasuk didalamnya perkemabangan Bahasaanak Berdasarkan Undang- Undang No.20 tahun 2003 menerangkan bahwa Taman Kanak-Kanak merupakan wadah pendidikan khususnya bagi anak usia dini, untuk dapat mengembangkan seluruh aspek yang ada di dalam diri anak seperti psikomotor, kognitif, dan afektif, Yang mana keseluruhannya terdapat dalam pembiasaan dan kemampuan dasar anak didik. Bahasa berfungsi sebagai salah satu alat komunikasi dan merupakan sarana penting dalam kehidupan anak. Melalui bahasa, anak dapat saling berhubungan, saling berbagi pengalaman, dan dapat meningkatkan intelektual, yakni dalam rangka pengembangan pengetahuan dan keterampilan bahasanya. Bagi anak di usia dini hal tersebut merupakan masa perkembangan yang harus dibina dan dikembangkan agar mereka dapat memanfaatkan kemampuan bahasanya 
secara maksimal. Tanpa adanya bimbingan dan arahan ikhawatirkan perkembangan bahasa mereka tidak sesuai yang diharapkan oleh orang tua di rumah maupun oleh pendidik di sekolah.untuk itu peneliti tertarik untuk melihat bagaiamanakah komunikasi pendidik PAUD terhadap perkembangan bahasa anak usia dini sekecamatan rumbai. rumusan masalahnya adalah:

a. Bagaimanakah bentuk komunikasi pendidik PAUD terhadap perkembangan bahasa anak usia dini sekecamatan rumbai?

b. Bagaimanakah perkembangan bahasa anak usia dini sekecamatan rumbai?

Komunikasi adalah hal penting dalam perkembangan bahasa anak usia dini. Selama komunikasi terjadilah proses belajar. Dengan komunikasi kita dapat mengetahui memahami dan merasaka pikiran atau pera saan orang lain. Komunikasi dilakukan sejak bayi dilahirkan dengan tangisan dan gerakan tubuhnya melaui orang disekelilingnya . komunikasi pendidik PAUD disekolah sangat dibutuhkan untuk perkembagana bahasa anak usia dini.

Pada dasarnya PAUD adalah wadah bagi balita untuk mengembangkan kemampuan komunikasi sejak kecil. Komunikasi merupakan salah satu aspek yang penting dalam pengembangan bahasa Anak Usia Dini. Anak-anak belajar menyerap informasi melalui interaksi harian dengan guru, orangtua anak-anak lain, orang dewasa dan dunia di sekeliling mereka. Antara usia 5-6 tahun, banyak anak masuk prasekolah atau TK, untuk itu guru menyiapkan kemampuan bahasa anak untuk masuk sekolah dasar. Steven (2009:96) menjelaskan "Semakin interaktif percakapan dengan anak, maka akan semakin banyak yang dapat dia pelajari". Membaca buku, bernyanyi, bermain katakata dan sekedar berbicara dengan anak dapat meningkatkan kosakata mereka. Di samping itu juga dapat meningkatkan kemampuan pendengarannya. Seiring perkembangan bahasa anak yang lebih baik, mereka semakin bagus dalam bercakap-cakap. Anak-anak usia 5-6 tahun dapat mengikuti arahanarahan yang kompleks dan secara antusias berbicara tentang hal-hal yang mereka kerjakan. Mereka dapat membuat cerita, mendengarkan cerita dengan seksama dan bercerita ulang. Pada Usia Dini, anak akan mengalami proses pembentukan karakter dengan stimulus yang diberikan oleh para orang tua dan guru yang mengajar di TK.

\section{Menurut Dhieni,}

(2006:1.1) "Bahasa adalah salah satu faktor yang mendasar yang membedakan manusia dengan hewan. Bahasa sebagai anugerah dari Sang Pencipta memungkinkan individu dapat hidup bersama dengan orang lain, membantu memecahkan masalah, dan memposisikan dirinya sebagai makhluk yang berbudaya".

Perkembangan bahasa sebagai salah satu dari kemampuan dasar yang harus dimiliki anak, sesuai dengan tahapan usia dan karakteristik perkembangannya. Perkembangan adalah suatu perubahan yang berlangsung seumur hidup dan dipengaruhi oleh berbagai faktor yang saling berinteraksi seperti biologis, kognitif, dan sosio-emosional. Bahasa adalah suatu sistem simbol untuk berkomunikasi yang meliputi fonologi (unit suara), morfologi (unit arti), sintaksis (tata bahasa), semantik (variasi arti), dan pragmatik (penggunaan) bahasa. Dengan bahasa, anak dapat mengkomunikasikan 
maksud, tujuan, pemikiran, maupun perasaannya pada orang lain (Nurzubaini, 2013:2).

Keterampilan anak dalam berbahasa perlu diasah sejak dini agar anak terbiasa berinteraksi dengan bahasa Indonesia. Sehingga kedepannya akan menunjang kelancaran anak dalam berkomunikasi menggunakan bahasa Indonesia. Perkembangan Bahasa Anak Usia Dini (PAUD) adalah salah satu aspek dari tahapan perkembangan anak yang diekspresikan melalui pemikiran anak dengan menggunakan kata-kata yang menandai meningkatnya kemampuan dan kreativitas anak sesuai dengan tahap perkembangannya. Perkembangan bahasa dimulai sejak bayi dan mengandalkan perannya pada pengalaman, penguasaan dan pertumbuhan bahasa. Pengembangan kemampuan berbahasa bagi Anak Usia Dini bertujuan agar anak mampu berkomunikasi secara lisan dengan lingkungannya.

Perkembangan bahasa anak usia dini, khususnya anak TK memiliki karakteristik tersendiri. Jamaris membagi perkembangan bahasa anak usia dini menjadi 2, yaitu:

a. Karakteristik kemampuan bahasa anak usia 4 tahun:

1) Terjadi perkembangan yang cepat dalam kemampuan bahasa anak. Anak sudah dapat menggunakan kalimat dengan baik dan benar.

2) Telah menguasai $90 \%$ dari fonem dan sintaksis bahasa yang digunakan.

3) Dapat berpartisipasi dalam suatu percakapan. Anak sudah dapat mendengarkan orang lain berbicara dan menanggapi pembicaraan tersebut. b. Karakteristik kemampuan bahasa anak usia 5-6 tahun

1) Sudah dapat mengungkapkan lebih dari 2500 kosakata.

2) Lingkup kosakata yang dapat diungkapkan anak menyangkut: warna, ukuran, bentuk, rasa, bau, keindahan, kecepatan, suhu, perbedaan, perbandingan jarak dan permukaan (kasar-halus).

3) Anak usia 5-6 tahun dapat melakukan peran pendengar yang baik

4) Dapat berpartisipasi dalam suatu percakapan, anak sudah dapat mendengarkan orang lain berbicara dan menanggapi pembicaraan tersebut.

5) Percakapan yang dilakukan oleh anak usia 5-6 tahun telah menyangkut berbagai komentaranya terhadap apa yang dilakukan oleh dirinya sendiri dan orang lain, serta apa yang dilihatnya. Anak pada usia 5-6 tahun sudah dapat melakukan ekspresi diri, menulis, membaca bahkan berpuisi.

Bromley (Dhieni, 2006:1.19) "Menyebutkan empat macam bentuk bahasa yaitu menyimak, berbicara, membaca dan menulis. Kemampuan berbahasa berbeda dengan kemampuan berbicara. Bahasa merupakan suatu sistem tata bahasa yang relatif rumit dan bersifat semantik sedangkan kemampuan berbicara merupakan suatu ungkapan dalam bentuk kata-kata”. Tarigan (2008:1) juga menyatakan "Keterampilan berbahasa mempunyai empat komponen, keterampilan menyimak, keterampilan berbicara, keterampilan membaca dan keteram pilan menulis". 
Hal senada dikemukakan oleh Carol Seefeldt dan Barbara A. Wasik dalam Bustomi (2012:23) bahwa terdapat empat komponen aspek perkembangan bahasa yaitu mendengarkan, berbicara, membaca dan menulis. Kempat keterampilan ini tidaklah mungkin dan juga tidak dianjurkan untuk secara mutlak untuk dipisahkan pembelajaran satu keterampilan dari pembelajaran keterampilan lain.

Seperti di sebutkan di atas, konteks pengembangan bahasa meliputi: mendengarkan, berbicara, membaca, dan menulis dini. Dalam mengembangkan kemampuan bahasa anak, guru/tutor dapat memilih strategi dan metoda secara bervariasi.

\section{METODE PENELITIAN}

Penelitian ini menggunakan metode deskriptif Kuantitatif, yaitu metode yang tidak memberikan perlakuan, manipulasi atau pengubahan pada variablevariabel bebas, teapi menggambarkan sesuatu kondisi apa adanya (McMillan dan Schumacher, 2001). Menurut Sukmadinata (2010), penelitian deskriptif bertujuan menggambarkan secara sistematis dan akurat fakta dan karakteristik mengenai populasi atau mengenai bidang tertentu. Data yang terkumpul dianalisis dan diinterpretasikan, kemudian dideskripsikan untuk menggambarkan kondisi yang terjadi pada subjek penelitian.

Mengadakan pengamatan langsung dari lapangan yang terkait dengan segala macam yang berkaitan dengan yang halhal diteliti antara lain keadaan lokasi penelitian, dan mengetahui bagaimana perkembangan kognitif anak usia dini ditinjau dari tingkat pendidikan Ibu

Pertanyaan dalam angket dapat berbentuk pertanyaan tertutup (berstruktur). Pertanyaan berstruktur adalah apabila dalam angket tersebut telah tersedia kemungkinan jawabannya. Wawancara dilakukan terhadap orangtua yang menjadi sampel Dalam penelitian ini.

Sebagai akhir dari suatu proses peneltian adalah analisis data, yaitu pengolahan data secara kualitatif dan analisis secara deskriptif karena penelitian ini bersifat gambaran dan menjelaskan mengenai permasalahan yang ada.

\section{HASIL DAN PEMBAHASAN}

Penelitian ini dilaksanakan di beberapa PAUD sekitaran Rumbai yaitu PAUD Mutiara Cendikia Ananda yang beralamat di Jln Sri Palas Perumahan Mutiara Palas Indah Peneliti mengadakan wawancara dengan Kepala TK, guru kelas dan guru pendamping, menyusun pedoman observasi berupa check list, dokumentasi dan catatan lapangan. Berdasarkan hasil wawancara, komunikasi dalam pembelajaran memiliki peranan sangat penting. Komunikasi dilakukan setiap akan dimulainya pembelajaran, dari hasil observasi yang dilakukan kepada Kepala TK, guru, dan orang tua murid yang dilakukan selama 3 kali pertemuan pada setiap pembelajaran komunikasi berjalan sangat interaktif. Informasi terkadang dari guru keanak dan terkadang juga dari anak ke guru, sehingga proses pembelajaran dikelas menjadi aktif. Selanjutnya, dari hasil studi dokumentasi yang dilakukan selama 3 kali pertemuan, peneliti memperoleh informasi tentang respon anak 
bervariatif, sebagian anak meresponsnya dengan senang dan ada beberapa anak yang kurang responsif; anak tidak fokus karena sibuk dengan kegiatannya sendiri. Berdasarkan hasil wawancara, terdapat faktor yang mempengaruhi pola komunikasi guru yaitu keterampilan guru dan kesiapan guru menyikapi anak dalam kelas, keterampilan guru dalam bertanya; penguasaan materi, metode dan media pembelajaran kemampuan dasar mengajar guru. Dari hasil wawancara yang dilakukan dengan kepala TK, guru dan orang tua murid kelompok B bahwa seorang guru tidak hanya memberikan informasi saat pembelajaran, tetapi guru juga harus menstimulus respon anak sehingga anak aktif memberikan informasi juga. Guru sangat berperan aktif ketika anak tidak aktif saat pemebelajaran, strategi yang dilakukan guru melakukan diskusi maupun simulasi bertujuan supaya anak dapat aktif sehingga komunikasi saat pembelajaran menjadi interaktif dan positif.

Berikut ini akan dibahas tentang hasil wawancara dan observasi peneliti terhadap komunikasi pendidik paud dalam perkembangan bahasa pada anak usia 5-6 tahun .

\section{Guru berkomunikasi dengan anak saat pembelajaran}

Komunikasi guru yang dilakukan di beberapa PAUD ini sudah terlaksana dengan baik. Hal ini terlihat dari kerjasama guru dan peran memperhatikan caracara guru memberikan informasi kepada anak saat pembelajaran. Guru tidak mendominasi pembicaraan tetapi memberikan stimulus kepada anak agar aktif juga untuk memberikan informasi sehingga komunikasi menjadi interaktif.

Dijelaskan oleh Wibowo (2002) bahwa komunikasi merupakan aktifitas menyampaikan apa yang ada dipikiran, konsep yang kita miliki dan keinginan yang ingin kita sampaikan pada orang lain. Atau sebagai seni mempengaruhi orang lain untuk memperoleh apa yang kita inginkan. Sejalan dengan itu Lloyd (dalam Nurbiana dkk, 2007:1.12) menjelaskan bahwa "Komunikasi merupakan pemindahan suatu arti melalui suara, tanda, bahasa tubuh dan symbol". Sehingga dari definisi di atas dapat disimpulkan bahwa tujuan komunikasi adalah untuk mendapatkan dampak (efek) kognisi yaitu berkenaan dengan pengetahuan, afeksi yaitu berkenaan dengan penyampaian perasaan atau pikiran, dan konasi yaitu berkenaan dengan perubahan sikap dan perilaku.

2. Respon anak terhadap informasi dalam pembelajaran

Pembentukan respon (Shaping Behaviour) adalah sebuah Teknik pembentukan respon yang dilakukan dengan cara menguatkan anak pada saat setiap kali anak bertindak kearah yang diinginkan sehingga anak menguasai atau belajar merespon sampai suatu saat tidak lagi menguatkan respon tersebut. Prosedur pembentukan respon bisa digunakan untuk melatih tingkah laku anak dalam proses pembelajaran agar secara bertahap mampu merespon stimulus dengan baik . Contoh : apabila seorang guru memberikan informasi, reaksi anak sebagai pendengar dapat mempengaruhi bagaimana guru itu bertindak. Jika sekelompok anak mengangguk - angguk kepala mereka, 
ini dapat menguatkan guru tersebut untuk berkomunikasi lebih semangat lagi. Komunikasi yang disampaikan oleh guru sangat jelas agar anak dapat merespon dengan baik. Untuk memacu anak-anak agar merespon setiap informasi yang disampaikan oleh guru, maka diadakan suatu diskusi dan simulasi agar anak lebih aktif saat pembelajaran. Pada saat diadakan diskusi dan simulasi respon anak akan bervariasi dalam menerima informasi dari guru. Semua anak merespon dengan baik, respon anak yang di berikan terhadap informasi yang disampaikan guru saat diskusi dan simulasi berlangsung sangat variatif. Anak sangat bersemangat dalam mengikuti kegiatan diskusi dan simulasi yang dibuat oleh guru. Kegiatan tersebut sangat bermanfaat untuk melatih anak dalam merespon informasi yang disampaikan oleh guru

\section{Guru merespon anak dalam pembelajaran}

$$
\text { Sebagai Guru tenaga }
$$

profesional di bidang pendidikan, di samping memahami hal-hal yang bersifat filosofis dan konseptual, juga harus mengetahui dan melaksanakan hal-hal yang bersifat teknis dalam merespon anak. Hal-hal yang bersifat teknis ini, terutama kegiatan mengelola dan melaksanakan interaksi belajar mengajar. Dalam pelaksanaan rutin setiap harinya guru menggunakan komunikasi banyak arah. Komunikasi guru saat pembelajaran tidak hanya melibatkan interaksi yang dinamis antara guru dengan anak tetapi juga melibatkan interaksi yang dinamis antara anak yang satu dengan yang lainnya. Proses belajar mengajar mengarah kepada proses pengajaran yang mengembangkan kegiatan anak yang optimal, sehingga menumbuhkan anak belajar aktif. Diskusi dan simulasi merupakan strategi guru untuk merespon anak dalam pembelajaran yang dapat digunakan guru untuk mengembangkan komunikasi. Guru harus bisa merespon anak dalam pembelajaran dengan membuat media pembelajaran menarik. Dalam kegiatan mengajar, anak memerlukan sesuatu yang memungkinkan dia berkomunikasi secara baik dengan guru, teman, maupun dengan ligkungannya. Oleh karena itu, dalam proses belajar mengajar terdapat dua hal yang ikut menentukan keberhasilannya yaitu pengaturan proses belajar mengajar dan pengajaran itu sendiri yang keduanya mempunyai ketergantungan untuk menciptakan situasi komunikasi yang baik yang memungkinkan anak untuk belajar.

4. Hambatan yang dialami guru dalam mengembangkan komunikasi dalam pembelajaran

Dalam kegiatan proses pembelajaran guru sering mengalami hambatan dalam berkomunikasi dengan anak. Hambatan yang biasa di alami oleh guru adalah kurang komunikatifnya anak saat guru bertanya, beberapa anak pasif waktu poses pembelajaran berlangsung. Guru yang lebih aktif dalam pembelajaran berlangsung karena tidak mendapat respon dari anak. 
5. Cara guru mengatasi hambatan dalam mengembangkan komunikasi dalam

\section{pembelajaran}

Dalam mengembangkan komunikasi, guru harus lebih kreatif dalam mengembangkan komunikasi dengan cara menanyakan hal yang paling disukai oleh anak, agar anak mau aktif juga dalam berkomunikasi. Guru lebih aktif lagi saat berkomunikasi dengan anak dalam menyampaikan informasi tentang media pembelajaran yang berlangsung, untuk mengembangkan komunikasi dalam pembelajaran guru lebih banyak menanyakan hal-hal yang menarik agar anak dapat merespon dengan senang dan mau berkomunikasi dengan guru.

\section{KESIMPULAN}

Berdasarkan penelitian yang telah dilakukan peneliti tentang pola komunikasi guru dalam pembelajaran pada anak usia 5-6 tahun di Rumbai, maka dapat diambil kesimpulan umum hasil penelitian ini adalah pola komunikasi guru dalam pembelajaran pada anak usia 5-6 tahun. Secara khusus dapat ditarik kesimpulan sebagai berikut :

1. Pola guru berkomunikasi dengan anak usia 5-6 tahun dalam pembelajaran di menggunakan pola komunikasi dua arah dan timbal balik. Ini berarti, dalam berkomunikasi di bangun interaksi yang dinamis antara guru dengan anak dan antara anak dengan anak. Upaya guru menanggapi respons anak dalam pembelajaran cukup baik, dimana guru menghargai, memberikan penguatan, dan memberikan kesempatan anak berbagi informasi kepada guru dan anak lainnya dalam memberikan informasi.
2. Guru merespons anak dalam pembelajaran cukup baik dimana menunjukkan sikap yang positif terhadap anak, ini dilihat dari sikap dan ucapan guru yang respek dan empati dengan anak yang punya keberanian untuk berkomunikasi dengan guru maupun teman-temannya. Faktor hambatan yang dialami guru dalam mengembangkan komunikasi dalam pembelajaran pada anak usia 5-6 tahun adalah masih ada beberapa anak yang masih kurang komunikatif, anak kurang merespon informasi yang disampaikan guru saat pembelajaran.

3. Faktor penunjang yang dilakukan guru dalam mengembangkan komunikasi dalam pembelajaran pada anak usia 5-6 tahun adalah media yang digunakan variatif sehingga dalam komunikasi menyampaikan informasi saat pembelajaran menjadi lebih menarik.

\section{DAFTAR PUSTAKA}

[1] Aisyah, Siti. 2007. Perkembangan dan Konsep Dasar Pengembangan Anak Usia Dini. Jakarta: Universitas Terbuka.

[2] Arikunto, Suharsimi 2010. Penelitian Tindakan Kelas. Jakarta: Bumi Aksara.

[3] Bachtiar. S, Bachri. 2005. Pengembangan Kegiatan Bercerita di Taman Kanakkanak. Jakarta : Depdiknas Dirjen PT Direktorat PPTK dan KPT.

[4] Bimo.2009. Teknik bercerita. ( Online. Jurnal Net. Com) 
[5] Budi Santoso, Eva magfiroh, dkk. 2010. Pemerolehan Bahasa Anak Usia 3 tahun dalam lingkungan keluarga. FKIP UNISMA. Malang.

[6] Hurlock, E.B. 1998. Psikologi Perkembangan Suatu Pendekatan Sepanjang Rentang Kehidupan. Jakarta: Erlangga.

[7] Hagan, Jessica S. 2006. Mendidik Anak Memasuki Usia Prasekolah. Jakarta: PT. Prestasi Pustakaraya.

[8] Hasan, Maimunah. 2011. Pendidikan Anak Usia Dini. Jogjakarta: Diva Press

[9] Soetjiningsih, Christiana Hari. 2012. Perkembangan Anak. Jakarta: Prenada Media Group.

[10] Yusuf, H. Syamsu. 2011. Psikologi Perkembangan Anak dan Remaja. Bandung: Remaja Rosdakarya. 